Man and Nature

L'homme et la nature

\title{
The German Enlightenment: Literaturgeschichte or Theologiegeschichte
}

\section{Timothy Pope}

Volume 5, 1986

URI : https://id.erudit.org/iderudit/1011859ar

DOI : https://doi.org/10.7202/1011859ar

Aller au sommaire du numéro

Éditeur(s)

Canadian Society for Eighteenth-Century Studies / Société canadienne d'étude du dix-huitième siècle

ISSN

0824-3298 (imprimé)

1927-8810 (numérique)

Découvrir la revue

Citer cet article

Pope, T. (1986). The German Enlightenment: Literaturgeschichte or Theologiegeschichte. Man and Nature / L'homme et la nature, 5, 153-163. https://doi.org/10.7202/1011859ar

Copyright (C Canadian Society for Eighteenth-Century Studies / Sociéte canadienne d'étude du dix-huitième siècle, 1986
Ce document est protégé par la loi sur le droit d'auteur. L'utilisation des services d'Érudit (y compris la reproduction) est assujettie à sa politique d'utilisation que vous pouvez consulter en ligne.

https://apropos.erudit.org/fr/usagers/politique-dutilisation/ 


\section{The German Enlightenment: Literaturgeschichte or Theologiegeschichte?}

Goethe, relating in Dichtung und Wahrheit of his forays into the arena of theological writing, recounts how he was drawn to the Bible through his study of Luther and how he was subsequently 'led astray' by Hamann and by the contemporary popularity of theology into composing and publishing theological essays of his own. He describes his first attempt at such an essay thus:

In eine der Hauptlehren des Luthertums, welche die Brüdergemeine noch geschärft hatte, das Sündhafte im Menschen als vorwaltend anzusehn, versuchte ich mich zu schicken, obgleich nicht mit sonderlichem Glück. Doch hatte ich mir die Terminologie dieser Lehre so ziemlich zu eigen gemacht, und bediente mich derselben in einem Briefe, den ich unter der Maske eines Landgeistlichen an einen neuen Amtsbruder zu erlassen beliebte. Das Hauptthema deselbigen Schreibens war jedoch die Losung der damaligen Zeit, sie hieß Toleranz, und galt unter den besseren Köpfen und Geistern. ${ }^{1}$

The letter in question was 'Brief des Pastors zu ${ }^{\star \star \star}$ an den neuen Pastor $\mathrm{zu}{ }^{\star \star *}$, written and published as Goethe's contribution to the keen debate going on in the 1770 s over the philosophically vexing doctrine of the sinfulness of man, the reality of hell and the devil, the damnation of the heathen and the heretical, and man's need for salvation. The 'Brief des Pastors' was followed in February 1773 by 'Zwo wichtige bisher unerörterte Biblische Fragen zum erstenmal gründlich beantwortet, von 
einem Landgeistlichen in Schwaben, ${ }^{2}$ in which Goethe tried his hand at Old and New Testament exegesis, adding, for good measure, his views on a subject made popular shortly before by Johann Joachim Spalding and others: the usefulness, or otherwise, of pulpit preaching. Goethe portrays his composition of these works as an interesting exercise rather more than as the fulfilment of a personal need, but the passage still illustrates a fundamental point in the eighteenth century: that theological questions were the burning questions of the time - questions that aroused the most intense public controversy, and that, at least up to Goethe's day, every thinking person felt a personal need to resolve to his own satisfaction. Theological questions were debated in literary societies, like Lenz's and Jung-Stilling's 'Gesellschaft der schönen Wissenschaften, ${ }^{\prime 3}$ and in journals like Friedrich Nicolai's Allgemeine Deutsche Bibliothek. Theologians, churchmen and laity alike joined in sending a constant stream of theological articles to the press so that these became the very bread and butter of such journals. Nicolai writes in 1771 to Lessing:

Wollte Gott ich dürtte an die ADB nicht mehr denken. Ich habe oft schon aufhören wollen; wissen Sie, was mich zurückhält? Die theologischen Artikel. Sie haben eine so merkwürdige Revolution in deutschen Köpfen verursacht, daß man sie nicht muß sinken lassen. Sie haben vielen Leuten Zweifel erregt und dadurch die Untersuchung rege gemacht. ${ }^{4}$

Conscious that theological book-reviews were not to everyone's taste Nicolai defends the high number published in the ADB by observing that over a quarter of all book-production was still in the area of theology, though the proportion was to fall to 6 per cent by $1800 .{ }^{5}$

The great theological questions had become hot issues because the orthodox answers that had held sway until the beginning of the eighteenth century were now deemed by leaders of the Enlightenment to be irreconcilable with reason. The spirit of tolerance had engendered a universalism that left no room for such doctrines as sin and damnation, hell and the devil, and salvation from sin through conversion. With these doctrines thrown into question, the task of the priest or preacher had to be reevaluated and redefined. What was he to preach? What continuity was there between Enlightenment theology, that was already a fait accompli in the popular press, and the orthodoxy of old, still firmly upheld in pietist circles and in most Lutheran pulpits?

This last question was a particularly vital and decisive one for the major literary writers who grew up in protestant parsonages. The number of these sons, who were ordinarily destined to follow in their father's footsteps, is particularly significant in the eighteenth century, though it is 
well known that Lutheran households and protestant seminaries have supplied leading thinkers and writers in every century since Luther. Emanuel Hirsch writes in his major history of protestant theology:

Es sind in der Mehrzahl Predigersöhne oder einstige Studenten der Theologie, von denen die Geschichte der deutschen Bildung und Dichtung in den ersten zwei bis drei Menschenaltern nach 1740 zu erzählen hat, und selten nur sind sie dem Christlich-Religiösen ganz fremd oder feind geworden. ${ }^{6}$

For many of these sons - for a Lessing and a Gottsched, for example there was no staying and going about their father's business. For them, orthodoxy raised questions that it could not answer, and it was outside of revealed Christianity - in philosophy, poetry or other secular areas - that new answers were to be developed. For a Herder, on the other hand, it was possible to remain within the Church and yet follow a course that diverged widely from orthodox Lutheran Christianity. Either way, theology, though it detached itself from its base in divine revelation, still remained the main field on which the battle for and against the new Enlightenment view of man was fought. Most literary history to the contrary, it may justly be claimed that theological developments were more important to literature in this century than purely rationalist ones. ${ }^{7}$ Literary developments arose out of a change in the perception of God, divine revelation and human nature.

In the field of theology, feelings ran high and debate was fierce. Then, as now, religion, of all the preoccupations of the time, provoked the strongest reaction, so that writers who are now best known for their role in literary history, if they expressed theological views in their time, became more notorious for those views than noted for their original contribution to literature. Lessing and Herder would have been thought of in their day by more people as religious free-thinkers than as theorists of literature and language and successful writers of drama and prose Lessing by virtue of his public disputes, most notably with Johann Melchior Goeze of Hamburg over the relationship of rationalism to revelation, and Herder by virtue of his creative, therefore unorthodox, writings and sermons. To someone like Pastor Lenz, father of J.M.R. Lenz and firmly orthodox superintendant of the Lutheran Church in Livonia, Herder was merely a theological deviant, a heretic. The poet Lenz protests in a letter to his father against such disparagement of Herder's real genuis: 'Sie tun Herdern unrecht, er ist kein Socinianischer Christ. ${ }^{8}$ Socinian was a term of abuse levelled by the orthodox at all who held sceptical, heretical or extreme religious views, though the term strictly applied only to those who followed the anti-trinitarian views of 
the sixteenth century Polish religious leader Socinus. Herder was indeed no Socinian but what he was was mystifying and disturbing to the orthodox. 'The pious Coleridge,' G.A. Wells relates in Herder and After, 'could not decide whether Herder was promulgating "intentional blasphemies or mere follies." And it needed Goethe's good offices with the duke of Weimer to procure Herder's appointment there in defiance of considerable orthodox opposition. ${ }^{\prime}$ A similarly dubious reputation was 'enjoyed' in his own day by Johann Christoph Gottsched, known to literary historians simply as the champion of French classical rules of form in drama and poetry, and to his younger contemporaries in the field of literature as an alien dictator in literary matters; but to most of those who heard of him in his day he would have been associated simply with religious scepticism. Gottsched was one of the first writers to occupy himself with a theological reinterpretation of Christian doctrines and in so doing to fall foul of the orthodox. The uncomfortable doctrine of the damnation of the heathen was one of the first to preoccupy him, as he relates in his 1757 preface to the 6th edition of Erste Gründe der gesammten Weltweisheit: Praktischer Teil, ${ }^{10}$ and in 1720 he wrote an academic dissertation on the subject, though it was then considered too unorthodox to publish. This early expression of sceptical views was followed fifteen years later by a series of papers, his 'Philosophische Abhandlungen,' delivered to an informal society from 1734-36, in which he challenged a number of orthodox doctrines: the existence of the devil, Miltonic conceptions of heaven and hell, the Fall, and revelation. At this time it was still too soon to risk such a stand in print. Christian Wolff had been dismissed from his chair at Halle for his perceived departure from orthodoxy and was not to be reinstated until 1740. The publication in 1757 of Gottsched's five papers as an appendix to his 'Weltweisheit' brought the expected hornet's nest down about his ears. That same year saw the publication of the first attempt at a rebuttal: Ziegra's 'Historische und critische Beurtheilung der durch des Herrn Professor G* der VI Aufl. seiner Philosophie beigefügten Anhang entstandenen Streitigkeit,' in which Gottsched is branded as a 'Poltermacher für Heiden' and 'Verkleisterer der Mängel der natürlichen Religion. ${ }^{11}$ It is evident that for the multitudes of the orthodox devout - for the majority of the reading public therefore - Gottsched thereby became known simply as an enemy of revealed truth, an underminer of Biblical theology. Later, as Goethe tells us in Dichtung und Wahrheit, the magus of the North, Hamann, was similarly to offend the pietists by his perceived impiety, just as it had been his piety, not his poetry, that had earlier won him a following among them (H.A.IX, 512f). 
The case of Gottsched reveals an important fact: the cause of Enlightenment theology was often furthered more by non-theologians than by specialists. Neology, as Enlightenment theology came to be known, was once again not an activity restricted to theologians but an intellectual exercise that all thinkers felt compelled to take part in. Within the discipline of theology, it was Johann Salomo Semler and J.F.W. Jerusalem who developed and popularised the new views. But most of their ideas were not original to them. In the opinion of one major historian of neology, Karl Aner, Gottsched himself was not merely an early neologian but the first neologian. His repudiation of the doctrine of eternal punishment in hell, expressed in 'Der Biedermann' of 1727-28, is picked up later by neology and becomes public through the dispute between Alberti and Goeze in 1769 over Alberti's treatment of the vindictive passage in Psalm 79, 6. Gottsched's questioning of the reliability of the witnesses to the resurrection anticipates Lessing's disqualification of the historicity of Christian revelation. Similarly his contemptuous denial of the concept of atonement, expressed in the third of his 'Philosophische Abhandlungen' where he asserts: 'Der Tod eines Tieres kann den meinigen unmöglich erkaufen; und wer kann sich das höchste Wesen so grausam vorstellen, daß es ohne Blut nicht versöhnt werden könnte,' was to become a commonplace in the decade of neology, the 1770s, where we find the poet Lenz writing somewhat irreverently to the theologically orthodox Lavater:

Hören Sie liebster Papa! ich habe eine Schrift von Ihnen gelesen die den Tittel führt. ... Keine Versöhnung geschieht ohne Blutvergiessen ... ich sag Ihnen nichts von den schönen Sachen die ich drinn gefunden - selbst die Hauptidee die vielleicht manchen kalten Grübler erwärmen ... aber mir gefällt es nicht, daß Sie unsern Gott wollen sterben lassen, weil es so seyn muß und in dem ganzen Naturreich alles Leben durch Tod eines andern erhalten werden muß. ${ }^{12}$

When Goethe's Iphigenie argues before Thoas that the gods require mercy and not sacrifice, the point hardly stands out any more, being no longer an issue in contemporary theological debate.

In Lenz's day neology was linked with the names of specialists such as the preacher Spalding, whose Betrachtung über die Bestimmung des Menschen, in which neology is best represented, went through thirteen editions after its first publication in 1748, and the theologians Johann Lorenz Mosheim and J.F.W. Jerusalem. Both are mentioned by Goethe in 1771 in a letter describing his new friend and mentor in Strasbourg, J.D. Salzmann, who himself seemed an incarnation of all that neology stood for. But the new anthropology and philosophy derived from neology 
was applied not by these specialists but by such non-theologians as Friedrich Nicolai, whose theologian-novel, Das Leben und die Meinungen des Herrn Magister Sebaldus Nothanker, became an immediate bestseller, and by educators such as Basedow, founder and director of the new school for orphans, the Philanthropin in Dessau. Basedow was well schooled in neology, being a former pupil of Hermann Samuel Reimarus, whose neological fragments brought greater notoriety to their editor and publisher, Lessing. The Philanthropin, in which Lenz was offered a post as writer in residence, was an institution designed to fulfill the social implications of neology. Kantzenbach writes:

Man wird gerade im Blick auf die philanthropische Bewegung den Einfluß eines der christlichen Offenbarung feindlich oder doch - im Blick auf ihren Inhalt völlig gleichgültigen Standpunktes, der der natürlichen Religion allein verpflichtet ist, nicht verkennen dürfen. Ein Basedow verschleierte nur aus äußeren Gründen, daß er im Grunde nichts anderes als die natürliche Religion vertrat. ${ }^{13}$

Against this background of intense discussion and eager application of new theological ideas, it is clearly no exaggeration to say that the German Enlightenment is just as much Theologiegeschichte as Literaturgeschichte. It is easy to see how Goethe in 1772 should come to be writing theological tracts and how one such as J.M.R. Lenz, though he too had left his father's house and like Gottsched, who was also the son of a Lutheran preacher, had chosen not to be about his father's business, came to write almost as much theology as fiction. Naturally, much of this fiction can be properly understood only in the light of the theology - a point that is important for a balanced understanding of the unfortunate Lenz. For religion in his life has almost always been viewed by posterity as merely a manifestation of psychological imbalance, not as a manifestation of a widespread preoccupation of his day. It is, however, this intellectual preoccupation rather than any pathological trait of character that is at the root of Lenz's Sturm und Drang philosophy, as surely as it is the theological issue that Lessing argued out with Goeze that underlies the plot of Nathan der Weise. The most characteristic element of this philosophy, the proclamation of 'Handeln, Handeln' as 'die Seele der Welt,'14 derives not from Lenz's whimsical or quixotic personality but directly from a theological discovery he made in early 1773 concerning the deity of Christ and the effectiveness of his atonement for human sin. This divine Genugtuung, as Lenz now understood it, removed the curse of failure and gave a sacramental quality to human action. It is in the spirit of this theological insight into the greatness of man's potential when he is under Grace and no longer under Law that Lenz's literary 
manifesto, Anmerkungen übers Theater was written later that same year. His definition of the modern-day dramatic hero distinguishes modern man on religious grounds from ancient man. 'Die Schauspiele der Alten,' he says, 'waren alle sehr religiös, und war dies wohl ein Wunder, da ihr Ursprung Gottesdienst war. ... Es was Gottesdienst, die furchtbare Gewalt des Schicksals anzuerkennen' (T.H.I. 357-58). With modern heroes of drama, he says:

es ist die Rede von Charakteren, die sich ihre Begebenheiten erschaffen, die selbstständig und unveränderlich die ganze große Maschine selbst drehen, ohne die Gottheiten in den Wolken anders nötig zu haben, als wenn sie wollen zu Zuschauern; nicht von Bildern, von Marionettenpuppen - von Menschen. Ha aber freilich dazu gehört Gesichtspunkt, Blick der Gottheit in die Welt, den die Alten nicht haben konnten, und wir zu unserer Schande nicht haben wollen. (343).

In Lenz the contemporary preoccupation with the concept of genius derives from the new view of God and man. In contrast to pietists like Jung-Stilling for whom the concept of the Genie ran directly counter to the passive Gelassenheit they regarded as the proper attitude to the creative activity of God, Lenz shores up the idea of poetic genius with theological arguments that have to do with a divine sanction for all human initiative, and a divine atonement that erases all the failures of the past.

If theological investigation was basic to literary writers of the eighteenth century - and literature often reflects the new theological understanding, whether it is the Miltonic poems of Klopstock, Lessing's Nathan or the Sturm-und-Drang writings of Lenz - the reverse holds true as well: that theology also reflects the trend to sensibility manifested in literature. New departures in neology parallel developments in the area of literary theory, in which traditional ideas were also contested in favour of ones that reflected the fundamental premise of the Enlightenment: that the key that unlocks truth is human reason and that the way to reason lies through the heart. Eighteenth-century writings on the nature of tragedy reveal a growing dissatisfaction with the notion that the purging of passions that was supposed to take place during the spectator's experience of a classical tragedy, came about through the arousal of terror as well as pity. Lessing downplays the idea of terror, Schrecken as Gottsched had translated it, and substitutes the word Furcht, arguing that it is merely the beginning of pity, Mitleid. He writes in a letter to Nicolai: 
Die Bestimmung der Tragödie ist diese: sie soll unsre Fähigkeit, Mitleid zu fühlen, erweitern. ... Das Trauerspiel soll so viel Mitleid erwecken, als es nur immer kann: folglich müssen alle Personen, die man unglücklich werden läßt, gute Eigenschaften haben, folglich muß die beste Person auch die unglücklichste seyn, und Verdienst und Unglück in beständigem Verhältnisse bleiben. ${ }^{15}$

On this view, tragedy arouses the sensibilities of the spectator as he weeps for the hero and fears for him, and so it improves him as a feeling human being. It moves him to virtue, it does not scare him into respect for the superiority of the gods or of fate. The same conviction that discounts the role of terror in the cathartic experience also, in a theological context, denies the element of fear in man's response to the atoning death of Christ. The pious response of man is no longer terror before the prospect of punishment for sin but tears at the sight of the suffering Saviour. Again it is the poet Lenz who provides the best example of this transition. His youthful poetry sees plagues sent by God and Christ upon man as a fearsome nemesis for his wrongdoing, and as late as 1772 he still sees the death of Christ as a sobering warning to man of the dire consequences of human evil. He writes in his personal catechism:

Eben diesen Nutzen hat auch zufälliger Weise die Aufopferung Jesu Christi ... daß sie uns die Abscheulichkeit der Sünde wie in einem Spiegel, oder wie in einem öffentlichen Schauspiel recht kläglich schrecklich und grausenvoll darstellen soll. ${ }^{16}$

As he shortly writes in a letter to Salzmann, however, the death of Christ is more than a wholesome warning to man of the consequences of his immorality. The passion is the supreme tragedy or sentimental drama. Arousing man to compassion it spurs him on in the imitation of Christ. Lessing's dictum, 'Der mitleidigste Mensch ist der beste Mensch,' is echoed in the statement Lenz makes in 'Uber die Natur unsers Geistes' (T.H.I.577): 'Zugleich hat er (Christus) uns ein Symbol geben wollen, was den vollkommenen Menschen mache und wie der nur durch allerlei Art Leiden und Mitleiden werde und bleibe.' Facing the tragic drama of Calvary man's response needs to be one of pity alone for the suffering hero. Though Lenz does make use elsewhere of the traditional concept of sacrificial atonement, in this passage the presentation of Christ's death is in line with the contemporary understanding. Neology had stripped this doctrine, as Lessing's dramaturgy had stripped the concept of tragedy, of all but its sentimental value. The rest it had rationalised away.

It was this rationalising away of most orthodox doctrines of the Christian faith that ultimately impoverished even their sentimental value. Too 
great a stress on reason and morality was proving, for many, still to be better food for the mind than for the heart. As Kantzenbach says:

Die Wurzel der Religion ist nach Spalding in der intellektuellen Wahrnehmung des moralischen Sittengesetzes zu sehen. Dieses Sittengesetz erkennt der Mensch. Durch Vernunft und Nachdenken stößt er auf die Notwendigkeit der Religion. ${ }^{17}$

The reaction against neology set in, among those who initially welcomed it, as early as the 1760 's. If it was literary writers who lead the trend towards natural theology, it is also literary writers who contribute to the reaction away from it. The orthodoxy of Klopstock's Messias was a much more exciting and satisfying alternative for the poets of the Göttinger Hain, Boie, Brückner, Miller, Hölty, who saw themselves as servants of theology through poetry in the tradition of Klopstock. In the decade of the Sturm und Drang the swing away from rationalism was also a swing away from rationalised religion. Though the concern with religious tolerance, expressed in Goethe's 'Brief des Pastors,' was fully in the spirit of neology, there are certain points that he makes here and in his other theological essay that aim at a restoration of the mystery, the sensuality, the supra-rational element of religion. For the sake of tolerance he has his Pastor defend the perceived Catholic idolatry of the person of Christ. It had been a commonplace in neology that Jesus was the teacher of religion, not the object of it. As Herder said, Christianity was Jesus' religion, it was not Jesus-religion. Goethe's essay says the opposite: 'Verflucht sei der, der einen Dienst Abgötterei nennt, dessen Gegenstand Christus ist' (H.A.XII, 233). Lenz, in his personal catechism, takes issue with Goethe's statement, arguing, in accordance with neology, that it is wrong to turn the One into God who was really the way to God. Paradoxically, Goethe's essay also agrees with this objection, but it is not long before Lenz retracts it. In a remarkable passage that indicates a complete rethinking of his christology, and in consequence anthropology, he emphatically asserts: 'Daß Jesus Christus derselbige einige ewige Gott sei den ich unter dem Namen des Vaters bisher angebetet.' This was the second reversion at this point in Lenz's life to an orthodox Christian doctrine. Just previously he had written to Salzman that the doctrine of atonement by Christ's life and death really did mean something after all, and all the more so now that he had come to a heightened doctrine of Christ. From this point on there is no more mention in Lenz of Spalding but a great, to the point of tub-thumping, preoccupation with orthodox evangelical theology.

Goethe's other published theological essay, 'Zwo wichtige bisher unerörterte Biblische Fragen zum erstenmal gründlich beantwortet, von 
einem Landgeistlichen in Schwaben,' makes two other points that tend away from the over-intellectualised Christianity as it had been defined by neology. Goethe's fictitious clergyman stands up for a simple religion of the heart, however incoherent, in contrast to the scholarly, sceptical rationalism of his son, the Magister of theology. 'Die einzige brauchbare Religion muß einfach und warm seyn,' says the Pastor; believers do not need conceptual theology but what they can use. Later in the article, in answer to the question: 'Was heißt mit Zungen reden?' the pastor comes out in favour of permitting the individual believer to cultivate the rationally inexplicable phenomenon of glossolalia. Ecstatic speaking in a spiritual tongue was not just local colour in the New Testament and irrelevant for modern man, he says. On the contrary, let the spirit speak: Wirft aber der ewige Geist einen Blick seiner Weisheit, einen Funken seiner Liebe einem Erwählten zu, der trete auf, und lalle sein Gefühl.'18 We should, of course, beware of taking Goethe's theological essays at face value as Lenz did. Christ occupied no prominent place in Goethe's religion, whether as an object of adoration or as the One who atones for man's sin. His stress on the Spirit, however, is characteristic of the renewed interest at the time in the supra-rational elements of religion, which manifested itself in more orthodox Christians as a longing once again for old-time religion. As Christian Fr. D. Schubart sums up in a letter of 1766 ,

Sie haben recht, unsere heutige Modetheologie ist so geistleer, schlüpft so über die Glasur unsers Herzen hinweg, daß ich den Menschen sehen möchte, den der Geist eines Spaldings (so groß er ist), eines Dieterichs, eines Ernesti, eines Semlers, eines Tellers und anderer auf dem Todtenbette unterhalten und mit Freuden der Ewigkeit erfüllen könnte. Wenn ich denken will, so lese ich obige Theologen; will ich aber empfinden, warm empfinden was Gott und Religion sei, so ist mir ein herzliches Verslein aus einem alten Kirchenliede tausendmal schätzbarer als der rastlos rollende Schwung eines modernen Rhetors. ${ }^{19}$

Rationalism will continue to go its course, but it is periodic reactions such as this that add particular interest to the Enlightenment viewed as theology history.

\section{TIMOTHY POPE}

University of Lethbridge 


\section{Notes}

1 Goethes Werke, Hamburger Ausgabe (München; Beck 1981) IX, 511-12, hereafter referred to as H.A.IX.

2 In Max Morris, Der junge Goethe (Leipzig, 1910) III, 122-31.

3 See T.F. Pope, 'J.M.R. Lenz's "Literarischer Zirkel" in Strasbourg,' Seminar XX.4 (1984) 235-45.

4 Quoted in Karl Aner, Die Theologie der Lessingzeit (Halle, 1929; reprinted Hildesheim: Georg Olms 1964) 8.

5 Peter Pütz, Die deutsche Aufklärung (Darmstadt: Wissenschaftliche Buchgesellschaft 1978), 21ff

6 Geschichte der neuern evangelischen Theologie im Zusammenhang mit den allgemeinen Bewegungen des europäischen Denkens (Gütersloh, 1949-540) IV, 5

7 A truer picture is provided by Peter Pütz who highlights Kant's mention of a religious emphasis at the end of his essay 'Was ist Aufklärung?' and Lessing's approach to the problems of enlightenment via theology and religion, and summarises thus: 'Die beiden vorausgehenden Kapitel haben gezeigt, wie lange und intensiv Aufklärung auf Religionssachen bezogen bleibt'(57).

8 Briefe von und an J.M.R. Lenz, ed. Karl Freye \& Wolfgang Stammler (Leipzig: Wolff 1918; reprinted Bern: Herbert Lang 1969) I, 142

9 G.A. Wells, Herder and After (S'-Gravenhage, 1959) 15

10 Johann Christian Gottsched, Ausgewählte Werke, ed. P.M. Mitchell (Berlin, New York: Walter de Gruyter 1983) V.2, 8

11 Gustav Waniek, Gottsched und die deutsche Literatur seiner Zeit (Leipzig 1897) 251

12 Briefe, I, 69

13 F.W. Kantzenbach, Protestantisches Christentum im Zeitalter der Aufklärung, Evangelische Enzyklopädie (Gütersloh, 1965) V-VI, 213-14

14 Werke und Schriften I, ed. Britta Titel and Helmut Haug (Stuttgart: Henry Goverts 1966) 378, hereafter abbreviated to T.H.I.

15 G.E. Lessing, Werke (München: Carl Hanser 1973) IV, $163 f$.

16 Gesammelte Schriften, ed. Franz Blei (München and Leipzig, 1913) IV, $38 \mathrm{f}$.

17 Kantzenbach, 199

18 Morris, 131

19 Kantzenbach, 180 